\title{
Postal ministry offers hope for German computer network users
}

Munich

THE future has brightened considerably for the users of academic computer networks in West Germany. After months of anxiety about the prohibitive and unpredictable cost of leased telephone lines, the West German postal ministry will announce this week that it will provide an all-purpose network of the X.25 type for academic use at fixed cost.

When IBM stopped paying for the European Academic Research Network (EARN) at the end of 1987, a scramble began across Europe to maintain the level of service EARN had provided (see Nature 328, 752-753; 1987). National organizations took over from IBM and lines were reshuffled to adapt to the wide variations in telephone rates. West Germany lost three of its five international lines, not only because of its high rates, but also because customers were charged according to the volume of their traffic.

Although university researchers in West Germany found other channels for their domestic correspondence, such as using the facilities of the Grossforschungseinrichtungen (Large Research Establishments or AGF), they faced an uncertain future from an apparently unsympathetic postal ministry.

But some time in the past year, postal ministry attitudes changed. Postal officials apparently stopped seeing the research community as just another special interest group with unreasonable expectations, and came to regard researchers as users who could help to demonstrate the ministry's new products and services that might also interest the more lucrative business market. Deregulation and the beginning of competition in telecommunications probably helped to bring about the change.

The postal ministry is reported to be offering researchers a network that will initially carry data at a speed of 64,000 bits per second (b.p.s), with the opportunity to increase the speed to 2 million b.p.s. The network will be available from mid1989 and will be administered by the German research network (Deutsche Forschungsnetz or DFN). The tariffs for the new network have yet to be determined but DFN is expecting a significant reduction from current charges.

The postal ministry has also asked DFN to develop technical standards for a pilot broad-band network capable of carrying data at 140 million b.p.s. Such networks depend on fibre-optics cables currently being installed by the postal ministry all over West Germany. They can be used, for example, for remote communication with supercomputers or for extremely detailed image transmission and manipu- lation. There are already a number of experimental broad-band networks in existence in West Germany, and apparently an increasing number of scientists are applying to the postal ministry for permission to install such facilities.

The future for international scientific networks in Europe remains uncertain despite the progress in West Germany (see Nature 329, 775-778; 1987). The postal ministries (PTTs) of the various European countries tend to see themselves as autonomous bodies with little interest in cooperation. EARN director Dennis Jennings of University College, Dublin, while greeting the "dramatic change" in West Germany as "fantastic", is concerned about "national boundaries that serve as international tariff walls". One attempt to lower the walls is called Managed Data Network Services (MDNS). It is being developed jointly by the PTTs to offer users 'one-stop shopping', that is, the opportunity to use international lines while dealing only with the local PTT. The first MDNS node is currently being installed in Holland, with others expected to follow soon.

Jennings views MDNS with caution, warning that it "does not [yet] exist" and will have a difficult birth, judging by EARN's experiences in negotiating with the various PTTs. Meanwhile, EARN continues to negotiate for corporate support to improve its facilities. The next year will bring further developments in this rapidly changing field. Steven Dickman

\section{A long and rocky road to reversing rainforest destruction}

\section{Washington}

Poor, short-sighted economic policies are to blame for the high rate of deforestation in developing countries, according to a report* by the World Resources Institute (WRI), a Washington-based think-tank concerned with the influence of public policy on the environment. The decimation of up to one-third of the developing world's forests since 1950 is only partly attributable to the practice of shifting cultivation, the conversion of forest land for agriculture and fuelwood gathering by local populations, the report concludes.

The report points a finger at the wellmeaning but mistaken policies adopted by developing countries to deal with their problems of poverty, urban overcrowding and trade imbalances.

Tropical countries in the developing world often take for granted the long-term benefits their forest resources can offer, and sell logging rights too cheaply. Logging concessions are usually not granted on a competitive basis, and are structured to turn over too frequently for the forests to regenerate, WRI finds. To compound the problem, internal political instability and corruption often mean that revenue received from logging concessions does not go directly into federal coffers.

Tax and other economic incentives designed to spur development by stimulating the forest industry can backfire. In some countries, the government may actually be paying concessionaires to come and take trees, because the amount of money that the government receives by selling access to its forests is negated by the loss in tax revenue and the administrative costs of managing the contracts, according to the WRI study. To keep some of the profits at home, many coun- tries have encouraged the development of wood-processing industries.

But the inefficiency of the plants and overly generous tax breaks and loan agreements mean that the processed products often bring in less money than would the export of the raw logs, while increasing the amount of forest that is destroyed.

To counteract the acceleration in the rate of tropical deforestation caused by misguided public policies, WRI recommends reforms in the granting of logging rights and the restriction of economic incentives. WRI is calling on the Food and Agriculture Organization (FAO) of the United Nations to incorporate these goals into the Tropical Forestry Action Plan developed by the FAO, the World Bank and the United Nations Development Programme last year. Carol Ezzell - The Smithsonian Institution is also turning its attention to rainforests. The Smithsonian has cooperated with the World Wildlife Fund to create "Tropical Rainforests: A Disappearing Treasure", an exhibition intended to familiarize the public with the present beauty and the tragic future of these forests. The exhibition opened on 21 May in the S. Dillon Ripley Center in Washington, DC.

The exhibition is a warning in hightechnology guise. It is intended to alert the public to the links between deforestation and the adaptation of land for agriculture, cattle ranching, timber operations and development projects. It also chronicles the effect of rainforest destruction on the world debt crisis and the growing human overpopulation.

Lisa L. Lyles

* The Forest for the Trees? Government Policies and the Misuse of Forest Resources, World Resources Institute, Washington DC, 1988 . 